Michał Bizoń

Uniwersytet Jagielloński, Kraków

ORCID: 0000-0002-7803-0854

e-mail:mfgbizon@gmail.com

\title{
Grecy, Witkacy i Czysta Forma w literaturze
}

DOI: http://dx.doi.org/10.12775/RF.2019.006

\section{Starożyłność w twórczości Witkacego}

Odwołania do starożytności są u Witkacego rzadkie. Choć koncepcja teatru formistycznego wykazuje zauważalne podobieństwa do pewnych cech teatru greckiego, w pismach Witkacego nie znajdziemy dłuższej analizy teatru czy poetyki greckiej w ogólności, a wzmianki nie tylko o poszczególnych sztukach, ale też o najbardziej znanych twórcach (np. Ajschylosie) są zdawkowe i nie niosą istotnej treści. Również w pismach filozoficznych i polemicznych Witkacy rzadko wspomina myślicieli starożytnych, a jego systematyczne polemiki filozoficzne dotyczą z reguły koncepcji autorów jemu współczesnych. Nic dziwnego: ramy tematyczne filozofii Witkacego, wyznaczone przez spory z fizykalizmem, filozofią języka i fenomenologia, umiejscawiają go mocno we współczesnych mu nurtach filozoficznych i zdają się pozostawiać niewiele nadziei na odszukanie w jego filozofii wątków starożytnych.

Badanie związków myśli Witkacego ze starożytnością grecką jest utrudnione również przez niejednoznaczne informacje odnośnie do jego wiedzy o literaturze i myśli tej epoki. W szczególności nie jest jasne, na jakim poziomie Witkacy władał językami klasycznymi. Kwestia ta może być o tyle istotna, że w czasach Witkacego nawet najlepsze przekłady były - oceniając według dzisiejszych standardów - obarczone interpretacją filozoficzną zabarwiającą ich treść. Niezdolność skonsultowania przekładu z tekstem źródłowym zaburzała zatem jego odbiór.

O poziomie wiedzy Witkacego odnośnie do języków starożytnych możemy wnioskować ze źródeł dotyczących jego wykształcenia śred- 
niego. Maturę zdawał (w roku 1903) w C.K. Wyższej Szkole Realnej we Lwowie, a wśród przedmiotów egzaminu pisemnego nie widnieje ani greka, ani łacina. Wiadomo natomiast, że greki uczyli się bracia Lilpopowie, rówieśnicy Witkacego, tak jak on mieszkający w Zakopanem i przygotowujący się do egzaminów maturalnych eksternistycznie ${ }^{1}$. Brak języków klasycznych wśród egzaminów maturalnych nie oznacza oczywiście, że Witkacy się ich nie uczył. Do egzaminów gimnazjalnych był przygotowywany $\mathrm{w}$ domu w Zakopanem przez prywatnych nauczycieli i ojca. Ten ostatni miał stanowcze i negatywne zdanie o publicznych szkołach - wyraził je z emfazą w Dziwnym człowieku, gdzie rykoszet dosięga także klasyki:

W naszych czasach - może trochę dawniej - wynaleziono sposoby zabijania samodzielnej przedsiębiorczości umysłu, łamania i rozluźniania energii twórczej, stawiając jako jedyny i ostateczny cel do osiaggnięcia: świadectwo dojrzałości! Nie nauka, nie wiedza, nie rozwój talentu, nie cnota - świadectwo dojrzałości! Ta szkoła, której się zdaje, że Grecy i Rzymianie byli w dziejach ludzkości tym, czym byli, dlatego że mówili po grecku i po łacinie; ta szkoła, która trzyma na obroży pięciu przynajmniej gramatyk przez szereg lat umysł dziecka i umysł człowieka dorastającego $[\ldots]^{2}$.

Ta filipika Witkiewicza-ojca mogłaby sugerować, że klasyczne wykształcenie, jako swoisty genius znienawidzonego przez niego sztywnego szkolnictwa państwowego, jest szczególnie objęte anatemą. Gdy jednak przyjrzeć się bliżej, sami „Grecy i Rzymianie” są w tej tyradzie ocenieni raczej pozytywnie - jako przykład twórczego wkładu w „dzieje ludzkości". Negatywnie ocenione jest jedynie spłaszczenie ich dziedzictwa przez szkolnictwo państwowe poprzez sprowadzenie go do samego tylko języka. Innymi słowy, ustęp ten sugeruje, że choć Witkiewicz-ojciec cenił klasyczną kulturę, to potępiał lub przynajmniej uznawał za nieprzydatne uczenie się greki i łaciny.

Wniosek ten potwierdzają dwie dalsze przesłanki. Pierwszą jest ironiczny komentarz Witkiewicza na temat przygotowań egzaminacyjnych wspomnianych braci Lilpopów: „U Lilpopów kucie. Radca szczegółowo wypytuje. Oro ze zdziwieniem wyziera z greckich tekstów" ${ }^{\prime 3}$. Po drugie,

1 Na temat matury Witkacego zob. Tomasz Pawlak, „Prywatysta Witkiewicz. O maturze Stanisława Ignacego Witkiewicza", Pamiętnik Literacki 2(2013): 205-218, gdzie przedrukowane są także pytania części pisemnej matury z przedmiotów: język polski, język niemiecki, język francuski, matematyka, geometria.

2 Stanisław Witkiewicz, Dziwny człowiek (Lwów-Warszawa: Towarzystwo Wydawnicze. Księgarnia S. Sadowskiego, 1903), 24 (cyt. za: Pawlak, „Prywatysta Witkiewicz. O maturze Stanisława Ignacego Witkiewicza": 209).

3 Cyt. za: Pawlak, „Prywatysta Witkiewicz. O maturze Stanisława Ignacego Witkiewicza": 209. 
Witkacy zdawał maturę pisemną z pięciu przedmiotów, w tym trzech języków: polskiego, niemieckiego i francuskiego. Witkiewicz-ojciec sarka zaś na "obrożę pięciu przynajmniej gramatyk”. Zakładając, że trzy $\mathrm{z}$ nich to te, które zdawał syn, pojawia się pytanie: o jakie (przynajmniej) dwie inne gramatyki chodzi? Nie można przecież wykluczyć, że właśnie o gramatyki klasyczne, przedmiot ciężkich zmagań Lilpopów. Dałoby to $w$ każdym razie asumpt Witkiewiczowi-ojcu do gorzkiego zapewnienia, że to nie one były odpowiedzialne za osiągnięcia "Greków i Rzymian”. Wydaje się zatem, że na złość C.K. bakałarzom Witkacemu nie było dane uczyć się języków klasycznych. Nieznajomość greki u Witkacego potwierdza jego młodszy przyjaciel Bolesław Miciński, sam zresztą greką i łaciną władający wyśmienicie. Nie ulega jednak wątpliwości, że Witkacy czytał w przekładzie dzieła literatury i filozofii klasycznej Grecji i Rzymu. Jak poniżej argumentuję, lektury te wywarły na jego myśli istotny wpływ. Ponieważ jednak Witkacy nie zajmował się autorami i zagadnieniami starożytnymi w sposób systematyczny, jego poglądy na te tematy trzeba wydobywać z rozproszonych wzmianek. Poniżej rozpatrzę je w związku z dwoma ogólnymi tematami, mianowicie związków greckiego teatru z koncepcją Czystej Formy w teatrze Witkacego oraz krytyki powieści jako dzieła sztuki.

\section{Teatr grecki jako prawzorzec teatru formistycznego}

Teoria Witkacego o formizmie $\mathrm{w}$ teatrze jest najobszerniej przez niego wyłożona w pracy Teatr i stanowi szczególne zastosowanie koncepcji Czystej Formy przedstawionej w Nowych formach w malarstwie. Według tej koncepcji istotową cechą sztuki czystej jest wywoływanie metafizycznego poczucia dziwności istnienia, przede wszystkim poprzez doznanie jedności w wielości. Znakomita większość sztuki do czasów Witkacego włącznie nie spełniała tego warunku z powodu skupienia się na wywoływaniu emocji i wrażeń lub przekazywaniu poglądów. W przypadku malarstwa ten „upadek" zaczął się w renesansie i wynikał ze stopniowego odrywania się sztuki od treści religijnych, które nadawały jej metafizyczny ładunek. Tymczasem, jak zauważa Witkacy, (nowożytny) teatr powstał stosunkowo późno, gdy nastąpił już znaczny zanik treści metafizycznych w sztuce ${ }^{4}$. Wynikałoby stąd, że od swoich początków w późnym renesansie teatr nigdy nie należał według Witkacego do sztuk czystych i różni się pod tym względem od innych dziedzin sztuki, w szczególności od malarstwa. Malarstwo formistyczne ma na celu odzyskanie poprzez nowe formy zdolności wywoływania wrażenia metafi-

4 Stanisław Ignacy Witkiewicz, "Teatr" i inne pisma o teatrze, oprac. Janusz Degler (Warszawa: Państwowy Instytut Wydawniczy, 1995), 14. 
zycznego, jakie wywierało malarstwo religijne średniowiecza i wczesnego renesansu. Tymczasem teatr formistyczny byłby przedsięwzięciem niemającym poprzedników. Wszak w samych początkach swego istnienia teatr, pozbawiony wymiaru religijnego i metafizycznego, był już skażony emotywną i światopoglądową treścią: ,[...] teatr, którego elementami są ludzie i ich działania, podobnie jak elementami malarstwa są kolory zamknięte $\mathrm{w}$ formy, a muzyki - dźwięki ujęte $\mathrm{w}$ rytmie, teatr musiał, przy postępującym zaniku uczuć metafizycznych, przejść w czyste odtworzenie życia"

Dotyczy to jednak jedynie teatru nowożytnego. Sztuka nowożytna - zwłaszcza malarstwo, a także muzyka - uzyskiwała wymiar metafizyczny jako wynik jej religijnej tematyki i wraz z odejściem od niej utraciła charakter sztuki czystej. Jednak dla Witkacego nie oznacza to przecież, że nie może istnieć niereligijna sztuka czysta. Sztuka czysta nie jest dla niego ancilla służalczo zależną od religii, lecz równoważną drogą do doznań metafizycznych: „,[c]ała sztuka ma źródło swe w metafizycznych uczuciach, podobnie jak religia, $\mathrm{w}$ dawnych czasach bezpośrednio z nią związana" 6 . Sztuka czysta może być wytworem religii, lecz nawet w takim wypadku dość szybko się od niej emancypuje: „[b]yło to nieraz udowodnione, że teatr powstał z religijnych misteriów". Mowa tu oczywiście nie o teatrze renesansowym, który nigdy nie miał wymiaru religijnego, a o teatrze greckim. Choć nowożytny teatr nie spełnia warunku bycia sztuką czysta, był czas, gdy istniał teatr prawdziwie metafizyczny (dzięki swemu religijnemu pochodzeniu), mianowicie w Grecji klasycznej: „[o]brządek religijny, tracąc swoje znaczenie bezpośrednie, rodzi teatr jako drugorzędny produkt swego upadku. O ile nam się zdaje, widać to dobrze na przykładzie Grecji, w której po raz pierwszy powstaje oddzielony od misteriów religijnych teatr"7.

Teatr ten zasadniczo różni się od niemetafizycznego teatru nowożytnego:

W Grecji ludzie szli do teatru prawdopodobnie dla innych zupełnie wrażeń niż my. Oni treść sztuk znali dobrze, bo treść ta była tylko pewną wariacją znanych wszystkim mitów. Na tle tej znanej treści, która była tłem metafizycznym stawania się na scenie, wszystko, co się działo, cały przebieg akcji, był tylko przez swoją formę spotęgowaniem elementu metafizycznego, który w życiu, oprócz wyjątkowych chwil ekstazy, coraz mniej zaczynali ludzie spotykać8.

\footnotetext{
5 Tamże.

Tamże.

Tamże.

Tamże, 18.
} 
Oto niespętany za młodu obrożą greckiej gramatyki Witkacy odnajduje $\mathrm{w}$ ateńskim teatrze pierwowzór swojego formizmu scenicznego. Ma ku temu kilka przesłanek. Po pierwsze, w tragedii greckiej (choć nie $\mathrm{w}$ komedii) treść utworu była na ogół nieoryginalna i nie stanowiła o wartości dzieła9. Podobnie zatem jak w teatrze formistycznym, nie "odtwarzanie życia" (a więc treść fabuły) jest głównym przesłaniem attyckiej tragedii. W odczytaniu Witkacego fabuła („cały przebieg akcji”) stanowi raczej materiał właściwej istoty sztuki, jaką jest „element metafizyczny". Uzyskiwany miał być on przez odpowiednie uformowanie („przez swoją formę") życiowej treści fabularnej. We wszystkich tych aspektach tragedia ateńska jest ściśle analogiczna do Witkacowskiego teatru formistycznego. Można do tego dodać, że podobnie jak teatr formistyczny tragedia ateńska nie czerpie według Witkacego swego metafizycznego wymiaru z treści religijnej (choć wywodzi się według niego z misteriów), jak miało to miejsce w przypadku wczesnego malarstwa europejskiego. Wreszcie, Witkacy jawnie - choć w formie dezyderatu porównuje funkcję swojego teatru formistycznego do teatru greckiego: „Czy możliwe jest powstanie, choćby na czas krótki, takiej formy teatru, w której współczesny człowiek mógłby niezależnie od wygasłych mitów i wierzeń tak przeżywać metafizyczne uczucia, jak człowiek dawny przeżywał je w związku z tymi mitami i wierzeniami?"10.

Do odczytania przez Witkacego charakteru tragedii attyckiej można poczynić dwa zastrzeżenia. Po pierwsze, odnoszenie do teatru greckiego z V wieku p.n.e. określenia "metafizyczny” jest ryzykownie anachroniczne, skoro "filozofia pierwsza" pojęta jako badanie "bytu jako bytu” zaczęła wykształcać się dopiero w IV wieku p.n.e. ${ }^{11}$ Anachronizm ten można jednak Witkacemu wybaczyć, wziąwszy pod uwagę, że termin „uczucie metafizyczne" pojmuje on sensu largo w analogii do np. doznań podczas misteriów religijnych. Po drugie, wątpliwości może budzić pewność Witkacego związana z przeżyciami antycznych widzów. Dysponujemy skąpymi informacjami odnośnie do odbioru utworów tragicznych przez Ateńczyków, a dostępne nam przekazy nie skupiają się na odczuwanych przez nich "metafizycznych uczuciach”. Sztuka Frynichosa Zdobycie Miletu, odnosząca się do tragicznie zakończonego tzw. powstania jońskiego, miała rzekomo wywrzeć silne wrażenie

9 Niektórzy tragicy modyfikowali jednak treść wykorzystywanych przez siebie mitów w celu osiągnięcia określonego wrażenia lub przekazania poglądu. Dotyczy to np. innowacyjnej roli przypisanej Atenie i areopagowi w Eumenidach Ajschylosa czy zmian w mitach z cyklu tebańskiego w Antygonie Sofoklesa. Bardzo oryginalnie przetwarzał materiał mityczny Eurypides.

10 Witkiewicz, "Teatr", 16.

11 Sam termin metaphysica powstał znacznie później, prawdopodobnie w I wieku p.n.e., jako neutrum plurale. Współczesna forma femininum singulare pochodzi z V lub VI wieku n.e. 
na ateńskich widzach, których skłoniła do płaczu (dalszych inscenizacji sztuki zakazano). Reakcja ta była jednak wywołana nie „uczuciem metafizycznym", lecz wspomnieniem utraconych bliskich i upadkiem ateńskiej kolonii ${ }^{12}$. Także teoria katharsis Arystotelesa wskazuje raczej na emocjonalny wymiar efektu wywieranego przez utwory tragiczne, co oczywiście nie mieści się $\mathrm{w}$ ramach sztuki czystej w ujęciu Witkacego ${ }^{13}$. Niezależnie jednak od tego, czy to Herodot, Arystoteles czy Witkacy trafniej odczytywali stany psychiczne doznawane przez Ateńczyków podczas Wielkich Dionizjów, jest jasne, że ten ostatni uznawał tragedię ateńską za sztukę czystą jako wywołującą wrażenia metafizyczne, a zatem traktował ją jako pierwowzór jego własnego teatru formistycznego.

\section{Powieść nie jest dziełem sztuki: u Witkacego i w Grecji}

Witkacy nie uważał powieści za dzieło sztuki. Podobnie jak jego krytyka nowożytnego teatru i konkurencyjna wobec niego koncepcja teatru formistycznego pogląd ten był konsekwencją koncepcji Czystej Formy. Istotę tej koncepcji Witkacy wyraził gnomicznie: „istotą sztuki jest forma”14. Tymczasem „w powieści (czy w nowelkach) nie chodzi nikomu o samą formę jako taka, tylko o przedstawioną przy pomocy tej formy rzeczywistości"15. W dziele sztuki natomiast powinna zachodzić relacja przeciwna: to rzeczywistość, treść życiowa, powinna być „tak zresorbowana $\mathrm{w}$ formalnej konstrukcji, aby można uważać ją za element nieistotny"16. Nie forma ma być narzędziem do przekazania pewnej treści, a raczej odpowiednio dobrane treści powinny służyć do stworzenia czysto formalnej „konstrukcji napięć kierunkowych”. Nie znaczy to oczywiście, że literatura nie może wyrażać treści czy mieć charakteru narracyjnego. Jednak to nie fabuła czy inne treści dyskursywne decydują o walorze artystycznym utworu literackiego, który zależy wyłącznie od jego konstrukcji formalnej.

Z tych samych powodów, dla których teatr formistyczny znajduje swój pierwowzór w tragedii attyckiej, także formistyczna krytyka bele-

12 Herodot, Dzieje 6.21.10.

13 Na temat związków teorii Czystej Formy Witkacego i poetyki Arystotelesa zob. Krzysztof Obremski, „Witkacy Arystotelesem "podszyty «. Mimesis i Czysta Forma”, Teksty Drugie 6 (1999): 139-147.

14 Stanisław Ignacy Witkiewicz, „Dlaczego powieść nie jest dziełem Sztuki Czystej”, w: Stanisław Ignacy Witkiewicz, Pisma krytyczne i publicystyczne (Warszawa: Państwowy Instytut Wydawniczy, 2015), 252.

15 Tamże, 262.

16 Tamże. 
trystyki jest w podstawowych aspektach zbieżna z greckimi koncepcjami literatury z okresu archaicznego i klasycznego. Podobnie jak Witkacy, Grecy uznawali formę, a nie treść, za cechę decydującą o artystycznym walorze utworu literackiego.

Grecka twórczość literacka rozwijała się w ramach gatunków określonych przez cechy formalne, zasady prozodii, cechy kompozycji, a nieraz także dialekt (np. dialekt epicki Homera i Hezjoda, doryckie części chóralne tragedii, eolska melika itd.). Kolejna cecha określająca utwór literacki to jego przeznaczenie. Literatura archaicznej i klasycznej Grecji była bez wyjątku performatywna, a więc przeznaczona do odbioru jedynie $\mathrm{w}$ określonych okolicznościach. Treść utworu była wtórna względem jego przynależności gatunkowej i performatywnego przeznaczenia. Oznacza to, że treść utworu modyfikowano, aby dostosować ją do konwencji gatunku i okoliczności wykonania. Źródła treści utworów literackich były względnie skąpe. Składały się na nie przede wszystkim powszechnie znane mity (najchętniej sięgano po cykl trojański i tebański). Rzadziej wykorzystywano współczesne wydarzenia polityczne (np. zwycięstwa na igrzyskach, jak w przypadku epinikiów). Ze względu na niewielki zasób wykorzystywanych tematów były one nieustannie przetwarzane i modyfikowane. Nieraz zmiany w treści wykorzystanego mitu wynikały z politycznej agendy autora (np. Eumenidy Ajschylosa). Treść mogła także być modyfikowana, aby spełnić wymogi gatunkowe lub stylistyczne ${ }^{17}$. Zmiany te jednak były niewielkie i nie ma świadectw, aby decydowały one o różnicach w ocenie kunsztu artystycznego twórców ${ }^{18}$. Słowem, w Grecji oryginalną twórczość literacką uprawiano przede wszystkim na płaszczyźnie formalnej utworu. W eposach homeryckich przewodni mit jest zrelacjonowany (prawdopodobnie) dość zachowawczo, innowacją autora są zaś mające znikomy wkład do fabuły tzw. porównania homeryckie. Największe różnice w twórczości attyckich tragików, wykorzystujących z niewielkimi zmianami te same

17 Np. Richard Jebb argumentuje, że w Antygonie Sofokles kazał Kreonowi najpierw pochować Polinejka, a dopiero później uwolnić Antygonę, gdyż pomimo nielogiczności i niekoherencji fabularnej właśnie taka kolejność miała lepszy wydźwięk retoryczny w przemowie relacjonującego wydarzenia posłańca. Względy retoryczne miałyby w takim wypadku większe znaczenie dla Sofoklesa niż logika fabuły. Zob. Richard Jebb, Introduction, w: Sophocles: The Plays and Fragments, Volume 3: The Antigone (Cambridge: Cambridge University Press, 1888), xix-xx.

18 Wymownym tego przykładem są Żaby Arystofanesa. W tej komedii autor porównuje jakość twórczości trzech tragików, Ajschylosa, Sofoklesa i Eurypidesa, poddając tego ostatniego miażdżącej krytyce. Opinia ta jest oparta na porównaniu prozodii i leksyki, nie zaś fabuły utworów. 
mity, zachodzą w regułach przedstawienia sztuki (stale zwiększająca się liczba aktorów) oraz w języku ${ }^{19}$.

Innowacyjność w greckiej literaturze dokonywała się zatem przede wszystkim w wymiarze formalnym, a nie materialnym utworu. Jest to ściśle związane z performatywnym charakterem greckiej literatury, która była przeznaczona do odczytu, śpiewu lub inscenizacji, a zatem jej brzmienie było kwestią pierwszorzędnej wagi. Najważniejsze z perspektywy artystycznej okazywały się więc takie czynniki, jak: dobór metrum (np. w częściach chóralnych tragedii i komedii), użycie figur stylistycznych i retorycznych, wreszcie styl języka. Można zaryzykować twierdzenie, że wymiar treściowy utworów był na tyle nieistotny, że celowo upraszczano fabułę, aby nie zaburzała odbioru formalnych aspektów dzieła. Porównajmy to ze stwierdzeniem Witkacego: „Istotą poezji jest synteza dźwiękowo-obrazowo-pojęciowa, stwarzająca to, co nazwałem "jakością poetycką złożoną« i czego konstrukcją w zmiennej proporcji elementów jest właśnie wiersz. Proporcja może być zmienna, ale zawsze wartość dźwiękowa jest nieomal w poezji najistotniejszą po czym idzie strona znaczeniowo-artystyczna $[\ldots]^{\prime \prime 20}$.

Poglądy Witkacego na poezję jako sztukę czystą są w kluczowych aspektach podobne do greckich zasad tworzenia poezji. Porównanie to można odnieść do beletrystyki, aczkolwiek w nieco przewrotny sposób. O ile bowiem Witkacy odmawiał powieści statusu dzieła sztuki, to Grecy szli dalej, gdyż do końca okresu klasycznego w Grecji nie istniała powieść jako gatunek literacki. Przed powstaniem noweli hellenistycznej literatura grecka miała zawsze formę poezji i zgodnie z powyższą argumentacją jej walor artystyczny był określany przez jej wymiar formalny. Utwory prozaiczne pojawiły się prawdopodobnie już w VI wieku p.n.e. (np. pisma Anaksymandra z Miletu), choć stały się powszechne dopiero na przełomie V i IV wieku p.n.e. (historycy, logografowie). Dzieła te miały jednak przeznaczenie praktyczne i nie były traktowane jako utwory literackie. W związku z odmiennym zastosowaniem i brakiem charakteru

19 Por. zawiły, gnomiczny język Ajschylosa, wystudiowaną retorykę Sofoklesa i potoczną attycką prozę Eurypidesa.

20 Witkiewicz, "Dlaczego powieść nie jest dziełem Sztuki Czystej”, 267. Por.: „Poezja czytana po cichu nie jest jeszcze sobą - jest tylko zaznaczeniem możliwości wykonania przez zaznaczone wyobrażenia słuchowe, połączone zawsze prawie z zaznaczonymi ruchami organów wydających dźwięki. Powieść taka, jaką jest obecna powieść (nie mówię o jakichś tam śpiewanych epopejach, bo to całkiem znowu co innego), jest przeznaczona do cichego czytania i wyobrażania sobie realnie przedstawionych w niej rzeczy, a nie do wywoływania artystycznych wzruszeń przez kombinacje aktualnych żywych jakości dźwiękowych i poprzez rytm odczuwany całym ciałem jakości [...]" (tamże). Ten opis doskonale pasowałby do określenia poezji, a tym samym całej w ogóle literatury greckiej, bez wyjątku przeznaczonej do wykonania na głos (a często zapewne niespisanej). Melodyczność była zatem podstawową cechą decydującą o walorze artystycznym utworu. 
performatywnego stosunek treści do formy tych utworów był w istocie odwrotny niż w przypadku literatury artystycznej. O ich wartości decydowała treść, a forma mogła być do tego stopnia nieistotna, że celowo ją upraszczano (np. Anaksymenes z Miletu ponoć napisał traktat językiem prostym i pozbawionym ozdobników, co zwróciło uwagę potomnych).

Zarówno Grecy, jak i Witkacy uważali, że o walorze artystycznym utworu literackiego decyduje nie jego treść, lecz wymiar formalny. Nie znaczy to jednak, że poglądy Greków na literaturę wyrażają koncepcję Czystej Formy Witkacego. Według tej teorii o byciu dziełem sztuki czystej decyduje nie tylko forma, ale także to, czy wywołuje ono uczucia metafizyczne. Jednak podobnie jak w przypadku tragedii attyckiej, także w przypadku pozostałej greckiej literatury jest rzeczą wątpliwą, czy jej celem było przede wszystkim wywoływanie uczuć metafizycznych. Jest prawdopodobne, że podstawowym celem greckiej liryki i tragiki było wzbudzanie odpowiednich emocji, co potwierdza także teoria katharsis Arystotelesa. Sam Witkacy zresztą nie uważał, aby poza tragedią literatura grecka spełniała warunki czystej formy. Iliada na przykład jest przez niego uznana za powieść poetycka, której istotę stanowi przekazywana przez nią treść, a nie forma. Oczywiście, nie jest w związku z tym dziełem sztuki czystej.

Choć można domniemywać, że poglądy większości Greków odbiegały od stanowiska Witkacego w uznaniu emocji, a nie wrażeń metafizycznych za właściwy cel poezji, to pojawiały się greckie głosy bardziej zbliżone do Witkacowskiej krytyki roli emocji w sztuce. Platon skrytykował poezję naśladującą za wywoływanie silnych uczuć poprzez sugestywne odtworzenie prawdziwych sytuacji życiowych i związanych z nimi fałszywych - ponieważ imitowanych - stanów emocjonalnych. Emocje takie opanowują duszę widza i odciągają ją od prawdy. Podobnie Witkacy zarzuca realistycznej - pozornie imitującej życie - literaturze otumaniający fałsz: „Teatr jest dziś stekiem najpotworniejszego kłamstwa, jest upadlającym narkotykiem [...]. Przecież zawsze musi się przyjść do tego wniosku, że się było nabranym i kwita"21. Jest tak dlatego, że: „W teatrze pojętym jako przedstawienie życia czy jako środek do wywołania pewnego nastroju uczuciowego, czy nawet jako środek rozstrzygnięcia pewnych problematów: życiowych, narodowych czy społecznych, jest implicite zawarty element kłamstwa"22. Fałszywość takiego teatru wynika - paradoksalnie na pozór - z jego realistyczności, tzn. ze skazanej na porażkę próby imitowania prawdziwego życia, "niedosiężnej doskonałości natury" ${ }^{23}$. W teatrze formistycznym natomiast ,[[n]ie mielibyśmy co prawda [...] tych dreszczyków czysto życio-

21 Tegoż, "Teatr", 73.

22 Tamże.

23 Tamże, 82. 
wych, ale widzielibyśmy na pewno, że nikt nas nie nabiera w ordynarny sposób, że to, co się dzieje na scenie, nie jest niedoskonałą imitacją czegoś, czego zupełna imitacja jest niemożliwa, tylko czymś kompletnie identycznym samym ze soba, tym właśnie, co być miało, a nie szeregiem sztuczek dla wywołania ułudy”24. Zatem: „Nie byłoby kłamstwa w teatrze takim [ $\mathrm{tzn}$. formistycznym, stanowiącym czysto formalną konstrukcję], ponieważ nie starałby się on nic imitować, nic udawać. Aktor [...] nie byłby udawaczem, byłby twórcą naprawdę"25. Tak jak Platon Witkacy odrzuca sztukę mimetyczną jako fałszywą dążącą do niemożliwej do zrealizowania imitacji prawdziwego życia. Dla obu sztuka winna być prawdziwa. W przypadku Platona realizowałoby się to, gdyby poezja odwoływała się do rozumu zamiast do łatwej do otumanienia części emocjonalnej duszy, dla Witkacego zaś sztuka powinna mówić $\mathrm{o}$ istnieniu. $\mathrm{W}$ obu przypadkach jest to postulat uczynienia sztuki metafizyczną. Nader platońsko - nie tylko przecież w krytyce udawanych emocji w teatrze, ale zwłaszcza w nadaniu sztuce metafizycznego celu jawi się Witkacy, gdy głosi „nowe horyzonty [...] teatru poza pojęciami śmiechu i płaczu, życiowego komizmu i tragizmu, teatru czystego, pozbawionego kłamstwa, a dziwnego jak sen, w którym przez wypadki niczym życiowo nie usprawiedliwione, śmieszne, wzniosłe czy potworne, przeświecałoby łagodne, niezmienne, z Nieskończoności promieniujące światło Wiecznej Tajemnicy Istnienia"26.

\section{Bibliografia}

Jebb Richard. 1888. „Introduction”. W: Sophocles: The Plays and Fragments, Volume 3: The Antigone. ix-l. Cambridge: Cambridge University Press.

Obremski Krzysztof. 1999. „Witkacy Arystotelesem »podszyty«. Mimesis i Czysta Forma". Teksty Drugie 6: 139-147.

Pawlak Tomasz. 2013. „Prywatysta Witkiewicz. O maturze Stanisława Ignacego Witkiewicza". Pamiętnik Literacki 2: 205-218.

Witkiewicz Stanisław Ignacy. 1995. "Teatr" $i$ inne pisma o teatrze. Oprac. Janusz Degler. Warszawa: Państwowy Instytut Wydawniczy.

Witkiewicz Stanisław Ignacy. 2014. „Nauki ścisłe a filozofia” i inne pisma filozoficzne (1933-1939). Oprac. Maciej Dombrowski i Magdalena Bizior-Dombrowska. Warszawa: Państwowy Instytut Wydawniczy.

Witkiewicz Stanisław Ignacy. 2015. „Dlaczego powieść nie jest dziełem Sztuki Czystej". W: Pisma krytyczne i publicystyczne. Oprac. Janusz Degler. Warszawa: Państwowy Instytut Wydawniczy.

\footnotetext{
24 Tamże, 75.

25 Tamże, 73.

26 Tamże, 76.
} 
Witkiewicz Stanisław. 1903. Dziwny człowiek. Lwów-Warszawa: Towarzystwo Wydawnicze. Księgarnia S. Sadowskiego.

\section{Streszczenie}

Tekst jest próbą odczytania twórczości Stanisława Ignacego Witkiewicza z perspektywy starożytnika. Na pierwszy rzut oka twórczość Witkacego niewiele oferuje badaczowi starożytności. Kontekst twórczości artystycznej Witkacego tworzą nurty malarskie i teatralne przełomu XIX i XX wieku. Tymczasem swoją filozofię artysta rozwijał w dyskusji ze współczesnymi mu nurtami fizykalizmu, fenomenologii i filozofii języka. Trudno też określić, na ile znał języki i teksty starożytne, na które powołuje się sporadycznie. Niemniej przy uważnej lekturze pism Witkacego okazuje się, że łączyło go z tradycją klasyczną więcej, niż mogłoby się wydawać. W tekście analizuję związki twórczości literackiej i filozoficznej Witkacego ze starożytnością grecką. Rozpatruję wpływ teatru greckiego na koncepcję teatru formistycznego, a następnie porównuję krytykę niebędącej dziełem sztuki powieści u Witkacego z funkcją utworów literackich w Grecji klasycznej oraz ich krytyka, w szczególności ze strony Platona.

Słowa kluczowe: Witkacy, Grecy, teatr, powieść

\section{Summary}

\section{Greeks, Witkacy and Pure Form in Literature}

The text is an attempt to read the works by Stanisław Ignacy Witkiewicz from the perspective of antiquity. At first, Witkacy's works do not offer much to the researcher dealing with antiquity. The context of Witkacy's artistic creativity is shaped by trends in painting and theatre at the turn of the 19th and 20th centuries. He developed his philosophy in a discussion with contemporary trends in physicalism, phenomenology and philosophy of language. It is also difficult to determine how deep his knowledge of languages and ancient texts was, and to which he refers only sporadically. Nevertheless, when carefully reading Witkacy's writings, he turns out to have more in common with classical tradition than one might initially think. In the text, I analyze the links between the literary and philosophical work by Witkacy and Greek antiquity. Firstly, I examine the influence of the Greek theatre on the concept of the formist theater and then compare Witkacy's criticism of the novel not considered a work of art with the function literary works played in ancient Greece and their criticism, in particular from Plato.

Keywords: Witkacy, Greeks, theatre, novel 